\title{
Origin of manganese in nannofossil calcite based on synchrotron nanoXRF and XANES
}

Baptiste Suchéras-Marx ${ }^{1, *}$, Fabienne Giraud ${ }^{2,3}$, Isabelle Daniel ${ }^{4}$, Camille Rivard $^{5, \S, !}$, Marie-

Pierre Aubry ${ }^{6}$, Karl-Heinz Baumann ${ }^{7}$, Luc Beaufort ${ }^{1}$, Rémi Tucoulou ${ }^{5}$, Alexandre Simionovici $^{2,3,8}$

1 Aix Marseille Univ, CNRS, IRD, INRAE, Coll France, CEREGE, Aix-en-Provence, France

2 Université Grenoble Alpes, ISTerre, Grenoble, France

3 CNRS, ISTerre, Grenoble, France

4 Univ Lyon, Univ Lyon 1, ENSL, CNRS, LGL-TPE, F-69622, Villeurbanne, France

5 The European Synchrotron, Grenoble Cedex 9, France

6 Department of Earth and Planetary Sciences, Rutgers University, Piscataway NJ 08854, USA

7 Department of Geosciences, University of Bremen, PO Box 330440, 28334 Bremen, Germany

8 Institut Universitaire de France (IUF)

Current affiliation:

$\S$ Synchrotron SOLEIL, Gif-sur-Yvette, France

+ TRANSFORM, INRAE, Nantes, France

* Corresponding author: sucheras-marx@ @erege.fr

\begin{abstract}
Calcareous nannofossils are micrometric calcite platelets secreted by coccolithophores and incertae sedis photosynthetic algae. Calcareous nannoplankton inhabit the photic zone from coast to open-ocean and have left an abundant fossil record since the Triassic. Therefore, they constitute an interesting material for geochemical studies although it has been overlooked in comparison to foraminifera. We have analyzed manganese distribution and valence in six calcareous nannofossil species representing different ages (Recent to Jurassic) and geological settings (land sections and deep ocean core-tops) and with different ultrastructures to assess the potential of $\mathrm{Mn}$ as paleobiological or paleoenvironmental proxy. Nano X-Ray Fluorescence (XRF) maps were established at the ESRF ID22NI and ID21 beamlines and Mn K-edge X-Ray Absorption Near Edge Structure (XANES) at ID21. Mn is more abundant in nannofossils from
\end{abstract}


the pre-Quaternary rock samples than from core-top samples. In nannofossil rock samples, Mn nanoXRF maps show distributions correlated with primary crystalline organization whereas in nannofossil core-top samples, $\mathrm{Mn}$ is either absent or doesn't follow the crystal organization. XANES analyses show that $\mathrm{Mn}$ is in the form of $\mathrm{MnCO}_{3}$. All these observations argue for $\mathrm{Mn}$ incorporation within calcareous nannofossils controlled by diagenesis through overgrowth of secondary calcite $(\mathrm{Ca}, \mathrm{Mn}) \mathrm{CO}_{3}$. Crusts grew along the original crystal growth directions. The incorporation of $\mathrm{Mn}$ in some core-top samples highlights potential early diagenesis input when the nannofossil lies on the seafloor or is still in the water column. Mn should therefore be considered a critical tool to identify diagenetic overgrowth rather than primary environmental conditions.

\section{Introduction}

Calcareous nannofossils are small calcite platelets $(1-30 \mu \mathrm{m})$ secreted by calcareous nannoplankton - coccolithophores and incertae sedis. Coccolithophores - and possibly most extinct calcareous nannoplankton - are photosynthetic, living in the photic zone (Winter et al., 1994). The coccolithophores are the most abundant unicellular calcifiers in the open ocean environment. They are also very abundant in more proximal or upwelling environments although less abundant than diatoms (Margalef, 1978; Ziveri et al., 1995). Hence, coccolithophores and, by analogy, extinct calcareous nannoplankton form a group covering most oceans and seas and living in the sea surface photic zone from coastal to oceanic gyre realms (Winter et al., 1994).

Calcareous nannofossils have accumulated in marine sediments since $210 \mathrm{Ma}$ (Bown, 1987; Gardin et al., 2012). Although they are rare in the Late Triassic, they became increasingly abundant through the Jurassic reaching an optimum in the Early Cretaceous (Suchéras-Marx et al., 2019). Calcareous nannofossil-based geochemical proxies are poorly developed. This limitation is firstly due to their micrometric size that prevented monospecific analyses until new methodologies developed to isolate calcareous nannofossils from bulk sediments (Stoll et al., 2009; Minoletti et al., 2009; Suchéras-Marx et al., 2016a) and perform elemental geochemical analyses over the last decade (Stoll et al., 2007; Suchéras-Marx et al., 2016b; Hermoso et al., 2017). The original chemical composition of calcareous nannofossils is also a challenge to the development of geochemical proxies because they are composed of low $\mathrm{Mg}$ calcite depleted in most elements, with concentrations typically below $\sim 10$ ppm (Siesser, 1977; Stoll et al., 2001; Prentice et al., 2014). Other than $\mathrm{Ca}, \mathrm{C}$ and $\mathrm{O}$, the most concentrated element in coccolith calcite is Sr, which, in Gephyrocapsa huxleyi (sensu Reinhard, 1972 and Bendif et al., 2014), 
represents ca. 0.6 wt \% of a coccolith (Stoll et al., 2002). Presently, the $\mathrm{Sr} / \mathrm{Ca}$ ratio is the only commonly accepted proxy based on calcareous nannofossil elemental composition. The $\mathrm{Sr} / \mathrm{Ca}$ depends on temperature and nannofossil growth rate, which, itself, is a function of a cell growth rates; $\mathrm{Sr} / \mathrm{Ca}$ is therefore used as a relative productivity proxy (Stoll et al., 2000; Rickaby et al., 2002; Stoll et al., 2002a; Stoll et al., 2002b). Calcareous nannofossils may yield, however, other geochemical environmental proxies and one of our main efforts has been to develop such proxies. Towards this objective, we present here a study of the distribution and valence of manganese $(\mathrm{Mn})$ in calcareous nannofossils.

$\mathrm{Mn}$ is a fundamental chemical element for oceanic primary producers, and although always in excess in sea water, it is biologically limiting (Bruland and Lohan, 2003). Mn is fundamental for photosynthesis, in that it is the key acting element in the oxygen-evolving complex in photosystem II, which photo-oxidizes water leading to the production of protons and electrons (Dismukes and van Willigen, 2006). Mn is more concentrated in coccolithophores than in green algae (Ho et al., 2003) suggesting a substantial implication of the element in coccolithophore physiology. $\mathrm{Mn}$ is also known to form the $\mathrm{MnO}$ complex in calcite tests of foraminifera (Pena et al., 2008) and has strong affinity for carbonate (Paquette and Reeder, 1995; Astilleros et al., 2002) particularly through diagenetic carbonate overgrowth (Boyle, 1983). We present here Mn distribution maps and valence based on synchrotron nanoXRF mapping and XANES in six nannofossil species which we have established with the objective to determine whether Mn has implication in nannoplankton photosynthesis chemistry (e.g. Mn-pool, Mn-waste or light shielding) or is incorporated in calcite during diagenesis. The samples and nannofossil species were selected in order to compare data from different i) ages (i.e., Middle Jurassic, Paleocene, and Quaternary), ii) localities with different environmental settings (i.e., Portugal, US, South Atlantic, Western Pacific and Norwegian sea), iii) morphologies and structures (i.e., five placoliths and one asterolith). We selected specimens larger than $4 \mu \mathrm{m}$ in diameter to overcome the limited spot size at the ID21 beamline (see section 2.2.2.). Such diverse panel of samples allowed identifying the influence of crystalline organization, geological time interval and diagenesis on $\mathrm{Mn}$ incorporation in calcareous nannofossils.

\section{Material and methods}

\subsection{Material}

The two Jurassic calcareous nannofossil species (Watznaueria britannica and Discorhabdus striatus) are placoliths from lower Bajocian (Middle Jurassic) marlstones outcropping in the Murtinheira section at Cabo Mondego, Portugal (latitude: 40.199773, longitude: -8.902904). 
This section is the reference for the Aalenian/Bajocian boundary (Pavia and Enay, 1997). W. britannica was isolated from sample $\mathrm{CM} 60\left(57 \mathrm{wt} \% \mathrm{CaCO}_{3}\right)$ and $D$. striatus from sample CM9 (52 wt\% $\mathrm{CaCO}_{3}$; see section in Suchéras-Marx et al., 2012). The Paleocene calcareous nannofossil Discoaster falcatus (Heliodiscoaster falcatus in Aubry, 2015) of the Order Discoasterales is an asterolith and is from the Marloboro Clay which characterizes the Paleocene/Eocene Thermal Maximum in the Wilson Lake core, NJ, USA (latitude: 39.655833, longitude: -75.047778; Miller et al., 2017). Quaternary calcareous nannofossil include 1) Helicosphaera carteri (helicolith) from South Atlantic core-top GeoB3721-4 (seafloor depth 3014 m, latitude: -25.151667, longitude: 12.40000) and from sediment core MD05-2920 in the western Pacific warm pool (sampling depth: $0.269 \mathrm{~m}$, seafloor depth -1849 m, latitude: 2.858000, longitude: 144.534000); 2) Calcidiscus leptoporus (placolith) from South Atlantic GeoB3721-4 core-top; 3) Coccolithus pelagicus (placolith) from the Norwegian sea GIK23066 core-top (depth seafloor: $-2795 \mathrm{~m}$, latitude: 68.253333, longitude: 1.006660). Material information are summarized in Table 1. Jurassic and Paleocene calcareous nannofossils are not as well-preserved recent core-top nannofossils. For each species, only one specimen was analyzed and presented in this study to the exception of $H$. carteri, one specimen was analyzed in nanoXRF whereas another was analyzed in XANES (see below).

\begin{tabular}{|c|c|c|c|c|c|c|c|c|}
\hline Species & Family & Order & Locality & Age & $\begin{array}{c}\text { Type of } \\
\text { nannofossil }\end{array}$ & $\begin{array}{c}\text { Sample } \\
\text { number }\end{array}$ & Sample holder & $\begin{array}{c}\text { Type of } \\
\text { analysis }\end{array}$ \\
\hline $\begin{array}{c}\text { Discorhabdus } \\
\text { striatus }\end{array}$ & Biscutaceae & $\begin{array}{c}\text { Podorhab } \\
\text { dales }\end{array}$ & $\begin{array}{c}\text { Cabo Mondego, } \\
\text { Portugal }\end{array}$ & $\begin{array}{c}\text { lower } \\
\text { Bajocian, } \\
\text { Jurassic }\end{array}$ & placolith & CM60 & $\begin{array}{c}500 \text { nm-thick } \\
\mathrm{Si}_{3} \mathrm{~N}_{4} \text { window }\end{array}$ & $\begin{array}{c}\text { nanoXRF, } \\
\text { XANES }\end{array}$ \\
\hline $\begin{array}{c}\text { Watznaueria } \\
\text { britannica }\end{array}$ & $\begin{array}{c}\text { Watznaueria } \\
\text { ceae }\end{array}$ & $\begin{array}{c}\text { Watznaue } \\
\text { riales }\end{array}$ & $\begin{array}{c}\text { Cabo Mondego, } \\
\text { Pojocian, } \\
\text { Jurassic }\end{array}$ & placolith & CM9 & $\begin{array}{c}500 \text { nm-thick } \\
\mathrm{Si}_{3} \mathrm{~N}_{4} \text { window }\end{array}$ & $\begin{array}{c}\text { nanoXRF, } \\
\text { XANES }\end{array}$ \\
\hline $\begin{array}{c}\text { Discoaster } \\
\text { falcatus }\end{array}$ & $\begin{array}{c}\text { Heliodiscoa } \\
\text { steraceae }\end{array}$ & $\begin{array}{c}\text { Discoaste } \\
\text { rales }\end{array}$ & $\begin{array}{c}\text { Wilson lake, NJ, } \\
\text { USA }\end{array}$ & Paleogene & asterolith & n/a & $\begin{array}{c}4 \mu \mathrm{m} \text {-thick } \\
\text { ultralene }\end{array}$ & $\begin{array}{c}\text { nanoXRF, } \\
\text { XANES }\end{array}$ \\
\hline $\begin{array}{c}\text { Calcidiscus } \\
\text { leptoporus }\end{array}$ & $\begin{array}{c}\text { Calcidiscace } \\
\text { ae }\end{array}$ & $\begin{array}{c}\text { Coccosph } \\
\text { aerales }\end{array}$ & $\begin{array}{c}\text { South Atlantic } \\
\text { core-top }\end{array}$ & Quaternary & placolith & $\begin{array}{c}\text { GeoB37 } \\
21-4\end{array}$ & $\begin{array}{c}4 \mu \mathrm{m} \text {-thick } \\
\text { ultralene }\end{array}$ & nanoXRF \\
\hline $\begin{array}{c}\text { Coccolithus } \\
\text { pelagicus }\end{array}$ & $\begin{array}{c}\text { Coccolithac } \\
\text { eae }\end{array}$ & $\begin{array}{c}\text { Coccosph } \\
\text { aerales }\end{array}$ & $\begin{array}{c}\text { Norwegian sea } \\
\text { core-top }\end{array}$ & Quaternary & placolith & $\begin{array}{c}\text { GIK2306 } \\
6\end{array}$ & $\begin{array}{c}4 \mu \mathrm{m} \text {-thick } \\
\text { ultralene }\end{array}$ & nanoXRF \\
\hline $\begin{array}{c}\text { Helicosphaer } \\
\text { a carteri }\end{array}$ & $\begin{array}{c}\text { Helicosphae } \\
\text { raceae }\end{array}$ & $\begin{array}{c}\text { Pontosph } \\
\text { aerales }\end{array}$ & $\begin{array}{c}\text { South Atlantic } \\
\text { core-top }\end{array}$ & Quaternary & helicolith & $\begin{array}{c}\text { GeoB37 } \\
21-4\end{array}$ & $\begin{array}{c}4 \mu \mathrm{m}-\text { thick } \\
\text { ultralene }\end{array}$ & nanoXRF \\
\hline $\begin{array}{c}\text { Helicosphaer } \\
\text { a carteri }\end{array}$ & $\begin{array}{c}\text { Helicosphae } \\
\text { raceae }\end{array}$ & $\begin{array}{c}\text { Pontosph } \\
\text { aerales }\end{array}$ & $\begin{array}{c}\text { Equatorial West } \\
\text { Pacific core-top }\end{array}$ & Quaternary & helicolith & $\begin{array}{c}\text { MD0529 } \\
20\end{array}$ & $\begin{array}{c}4 \mu \mathrm{m} \text {-thick } \\
\text { ultralene }\end{array}$ & XANES \\
\hline
\end{tabular}

Table 1: Calcareous nannofossils species, taxonomy, sampling locality, age, type of nannofossil, sample number, type of sample holder and type of analysis.

\subsection{Sample preparation}

The calcareous nannofossils analyzed in this study were picked following Suchéras-Marx et al. (2016a). The Jurassic and Paleocene rocks were first powdered. Then, alongside with the four Quaternary core-top sediments, one to several smear slides were prepared from all samples, 
using ethanol to separate sedimentary particles. Nannofossils were then hand-picked with a glass-silica needle. Each picked nannofossil was deposited on the dedicated sample holder using an ethanol droplet. No other chemical treatment was performed. Nannofossils were selected based on optical criteria - best preservation and large size - using a 400X magnification light microscope. Jurassic calcareous nannofossils were mounted on $500 \mathrm{~nm}$-thick silicon nitride $\left(\mathrm{Si}_{3} \mathrm{~N}_{4}\right)$ windows (Silson Ltd. Southam, UK). These spectroscopically pure ultrathin membranes were chosen to limit as much as possible the contribution of the substrate to the measured fluorescence spectra and because Si emission energy was below the energy range of interest. The Paleocene and Quaternary nannofossils were deposited between two $4 \mu \mathrm{m}$-thick sheets of Ultralene (SPEX®), a clean and pure polymer. This type of sample holder was selected because it is free of the elements of interest in the energy range of interest. This information is summarized in Table 1. The background contribution shown in Figs.1-2 is estimated from pixels around the nannofossil. This includes several contributions such as ethanol used in sample preparation, membrane and parasitic multiple scattering to the spectra and is treated as the background.

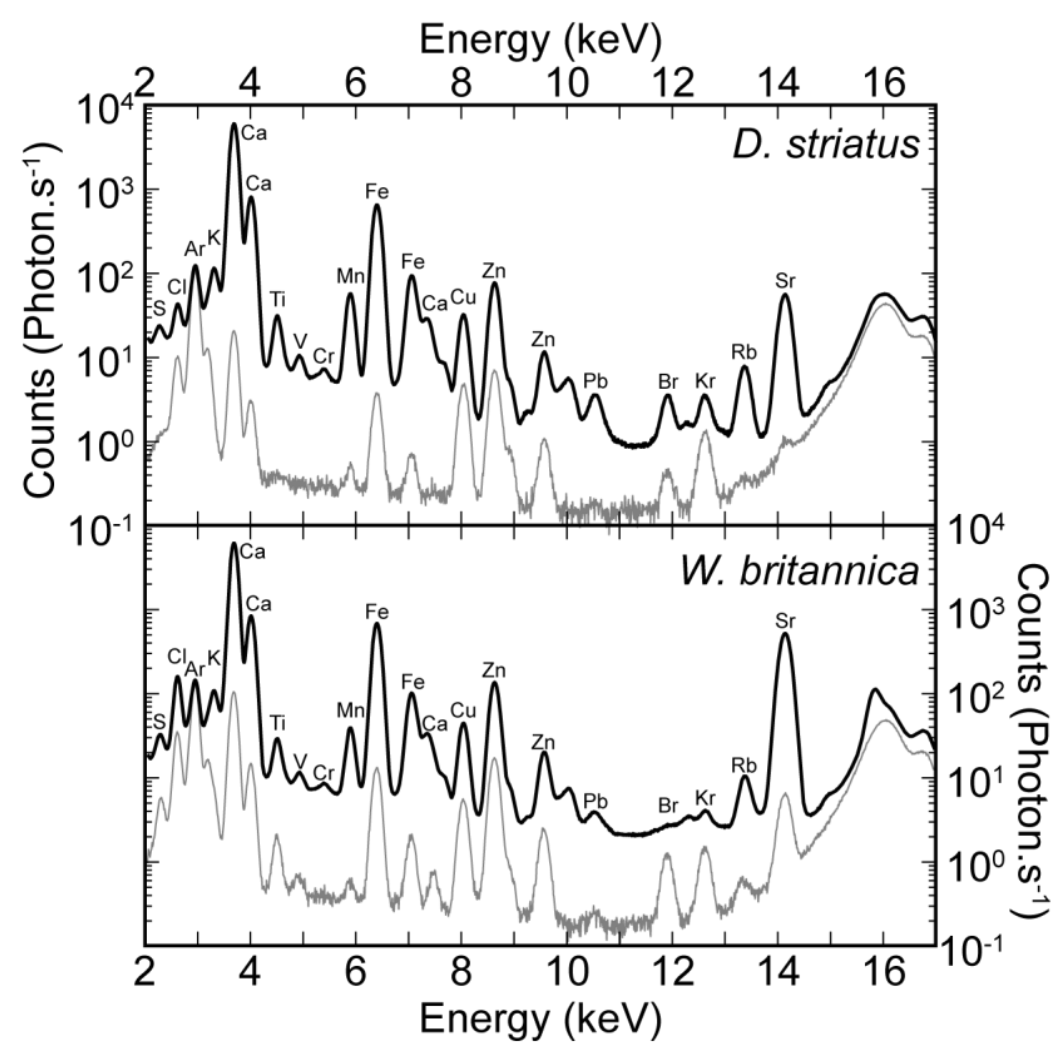

Fig. 1: XRF spectra of D. striatus and W. britannica $(17 \mathrm{keV})$. The black line corresponds to the average spectrum considering the whole nannofossil compared to the gray line which shows the contribution of the background. 


\subsection{XRF mapping}

\subsubsection{NanoXRF mapping at ID22NI}

Both $W$. britannica and $D$. striatus were analyzed using a monochromatic incident X-ray energy of $17 \mathrm{keV}$ at the ID22NI beamline (currently replaced by ID16b) of the European synchrotron Radiation Facility (ESRF, Grenoble, France), with a $100 \mathrm{~nm}$ x $100 \mathrm{~nm}$ beam focused by an ESRF custom-made Kirkpatrick-Baez (KB) double multilayer mirror device and $2 \mathrm{~s}$ dwell time per pixel. The detectors were high-count rate twin SII ${ }^{\mathrm{TM}}$ Vortex SDD (silicon drift diodes) detectors, capable of counting up to $210^{5}$ counts per second when operated below $10 \%$ dead time. The maps were produced by 2D scanning of the sample in the focused beam. The maps were measured during project EC811, which focused on high-resolution mapping of Sr published in Suchéras-Marx et al. (2016b). In this study, they are used as a control to compare with lower energy maps collected at ID21, which spatial resolution is lower than at ID22NI.
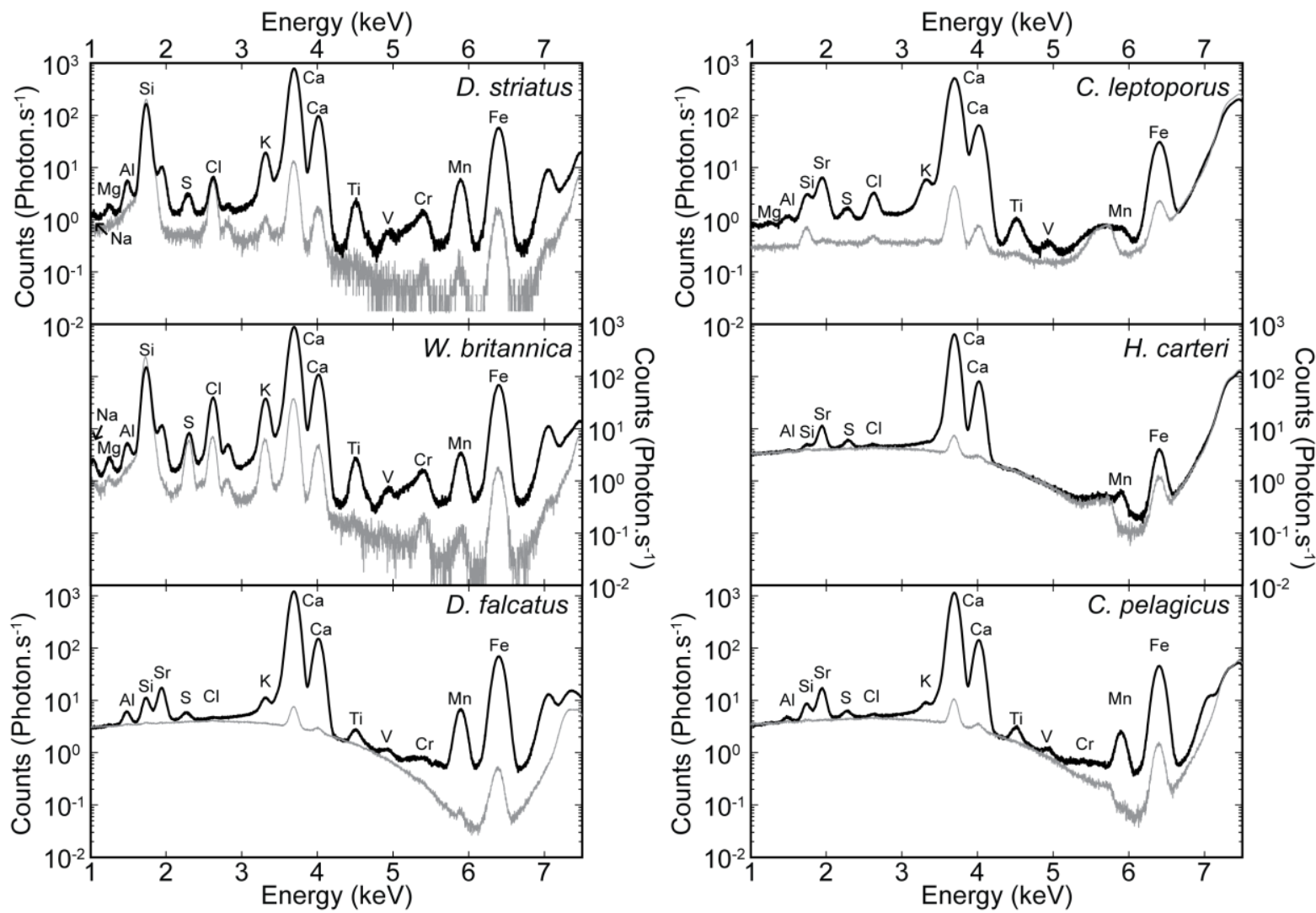

Fig. 2: XRF spectra of D. striatus, W. britannica, D. falcatus, C. leptoporus, H. carteri and C. pelagicus $(7.5 \mathrm{keV})$. The black line corresponds to the average spectrum considering the whole nannofossil compared to the gray line which shows the contribution of the background. (partly represented by the sample holder; $\mathrm{Si}_{3} \mathrm{~N}_{4}$ window for D. striatus and W. britannica, ultralene foil for the others). 


\subsubsection{MicroXRF mapping at ID21}

X-ray fluorescence (XRF) maps and X-ray Absorption Near Edge structure (XANES) spectra were collected at the ID21 X-ray microscopy beamline of the ESRF (Cotte et al. 2017) through project ES113. The beam was monochromatized by a fixed-exit, double crystal Si(111) monochromator. The incident beam was focused to $230 \mathrm{~nm}$ x $750 \mathrm{~nm}$ using mirrors in $\mathrm{KB}$ geometry. The fluorescence signal was collected using a $10 \mathrm{~mm}^{2}$ Rontec SDD detector located $24 \mathrm{~mm}$ away from the sample, at $69^{\circ}$ with respect to the incident beam and $49^{\circ}$ with respect to the surface of the sample. The dead time was between $9 \%$ and $15 \%$ during analysis. The microscope was operated in vacuum to avoid absorption and scattering from air. W. britannica, D. striatus, $H$. carteri and C. pelagicus were mapped with $400 \mathrm{~nm}$ horizontal and vertical steps and $3 \mathrm{~s}$ dwell time per pixel, D. falcatus with $500 \mathrm{~nm}$ horizontal and vertical steps and $3 \mathrm{~s}$ dwell time per pixel and C.leptoporus with $200 \mathrm{~nm}$ horizontal and vertical steps and $1.5 \mathrm{~s}$ dwell time per pixel. The $7.5 \mathrm{keV}$ mapping at ID21 was selected in order for the incident beam energy to be as close as possible to Mn excitation energy hence optimizing fluorescence yield and allowing the detection of minute amounts of Mn.

\subsection{XANES analysis}

XANES refers to the variations of the absorbance of X-rays in the near vicinity of an absorption edge of an element (Herweg, 1913; Bianconi, 1980). The fine hyper structure of an absorption spectrum within $\sim 50-100 \mathrm{eV}$ around the absorption edge depends on the oxidation state of the analyzed element. XANES spectroscopy is usually based on comparison of absorption measured on the sample and on standards of known composition to determine the chemical species present in the sample.

For Mn K-edge XANES analyses, the monochromator energy was calibrated using the edge of a Mn metallic foil at $6.5495 \mathrm{keV}$. The incident beam was focused to $250 \times 820 \mathrm{~nm}^{2}$. Three standards, namely $\mathrm{KMnO}_{4}, \mathrm{MnO}_{2}$ and $\mathrm{MnCO}_{3}$ and four nannofossils $D$. striatus, W. britannica, $D$. falcatus and H. carteri were analyzed. For both standards and nannofossils, Mn K-edge XANES was collected in the $6.52-6.60 \mathrm{keV}$ energy range with $0.5 \mathrm{eV}$ step and $50 \mathrm{~ms}$ per step. For each standard, 10 XANES spectra were collected. For each nannofossil, 50 XANES spectra were collected. The spectra for each standard hereafter correspond to the average of all XANES spectra. The spectra for D. falcatus and W. britannica spot C correspond to the average of all XANES spectra per nannofossil; for $D$. striatus 48 XANES spectra were considered whereas for H. carteri and W. britannica spots A-B-D 10 XANES spectra were considered for the normalization. The normalization was performed with Demeter 0.9.21 software. The exclusion 
of some XANES spectra for the normalization in some samples was done to limit the noise around average. This was a trade-off between statistics and radiation damage to the samples. However, these exclusions did not dramatically change the global aspect of the spectra.

\section{Results}

\subsection{XRF spectra}

Exciting fluorescence in D. striatus and W. britannica at $17 \mathrm{keV}$ allowed to observe the contribution of 17 elements, S, Cl, Ar, K, Ca, Ti, V, Cr, Mn, Fe, Cu, Zn, Br, Kr, Rb, Sr and Pb (Fig. 1). Among them, Ar and $\mathrm{Kr}$ come from the air. $\mathrm{Pb}$ is not considered in the following being the main component of the experimental hutch shielding. Detection of $\mathrm{S}, \mathrm{Cl}, \mathrm{K}, \mathrm{Ca}, \mathrm{Ti}, \mathrm{V}, \mathrm{Cr}$, $\mathrm{Mn}, \mathrm{Fe}, \mathrm{Cu}, \mathrm{Zn}, \mathrm{Br}, \mathrm{Rb}, \mathrm{Sr}$ is in good agreement with earlier observations on W. britannica (Suchéras-Marx et al., 2016b). The spectra collected at $7.5 \mathrm{keV}$ provide the distribution of $\mathrm{Mg}$, $\mathrm{Na}$ and $\mathrm{Al}$ in D. striatus and W. britannica; the $\mathrm{Si}$ signal mainly comes from the $\mathrm{Si}_{3} \mathrm{~N}_{4}$ membrane (Fig. 2). At $7.5 \mathrm{keV}$, the XRF spectra of D. falcatus, C. leptoporus, H. carteri and C. pelagicus differ from those of $D$. striatus and W. britannica. However, they all confirm the presence of $\mathrm{Al}, \mathrm{Si}, \mathrm{Sr}, \mathrm{S}, \mathrm{Cl}, \mathrm{Ca}, \mathrm{Mn}$ and $\mathrm{Fe}$. Some of them also show the presence of $\mathrm{K}, \mathrm{Ti}, \mathrm{V}$ and $\mathrm{Cr}$. In both set-ups, the contributions from the $\mathrm{Si}_{3} \mathrm{~N}_{4}$ window and ultralene membrane holding the nannofossils are shown in Fig. 1 and Table 2.
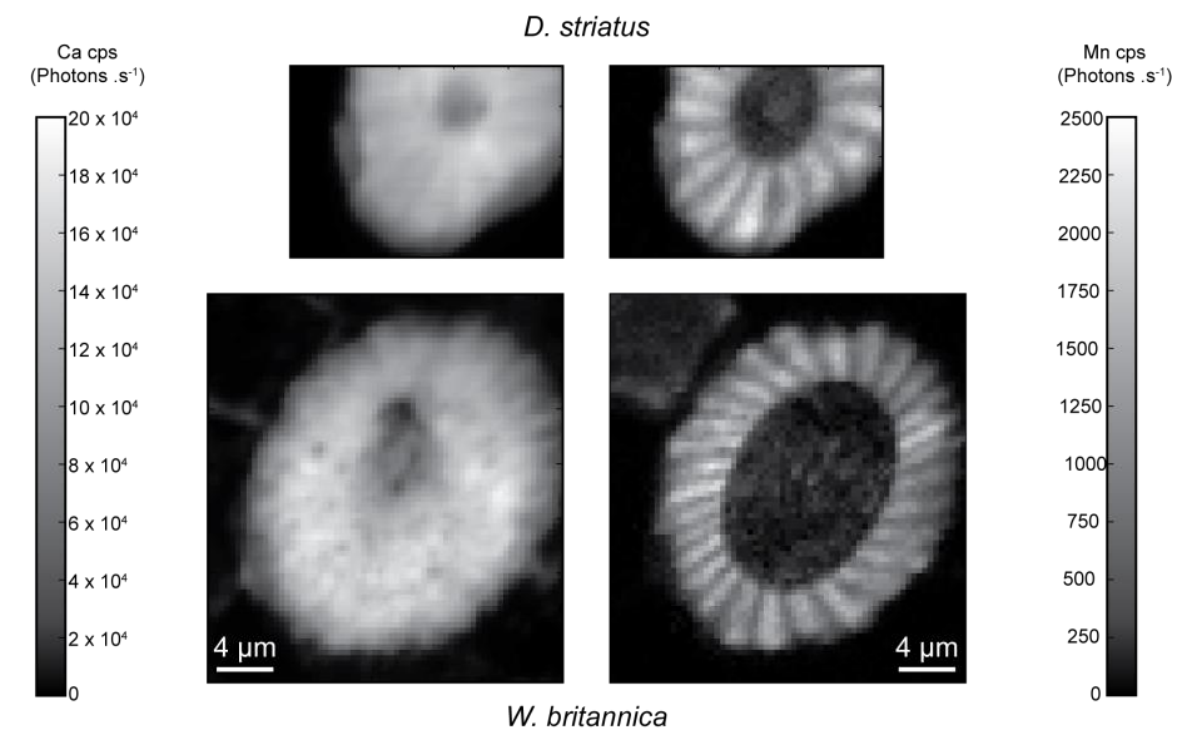

Fig. 3: Ca and Mn maps of D. striatus and W. britannica $(17 \mathrm{keV})$. Both intensity gray scales are in photon counts per second. 
At $17 \mathrm{keV}, \mathrm{Mn}$ is clearly and consistently recorded in D. striatus and W. britannica s with a negligible contribution from the membrane. At $7.5 \mathrm{keV}, \mathrm{Mn}$ is clearly recorded in in these latter two species, D. falcatus and C. pelagicus and poorly in H. carteri (Fig. 2). The membrane contributions remain, in most case, negligible (Table 2). These contributions of $\mathrm{Mn}$ and other elements from the sample holders may come from the membranes themselves, the ethanol drop used during the picking procedure (Suchéras-Marx et al., 2016a) or from residual elements leached from clay in the ethanol during the preparation.

\subsection{Manganese maps}

Ca and Mn elemental maps for D. striatus and W. britannica were measured at ID22 (Fig. 3); those for D. striatus and W. britannica, D. falcatus, C. leptoporus, H. carteri and C. pelagicus were analyzed at ID21 (Fig. 4). Ca elemental maps are considered hereafter as the reference for calcareous nannofossil calcite crystal organization and global shape. For the placoliths and the helicolith, the global sub-circular to elliptical shape and the open to less calcified central area are observed whereas for the asterolith, the star-shape and a central knob are clearly observed. D. falcatus has a proximal and a distal knob but those cannot be separated in 2D maps. Only in D. striatus and W. britannica analyzed at $17 \mathrm{keV}$, the crystals are observed in Ca maps (Fig. 3; Suchéras-Marx et al., 2016). For D.falcatus, C. leptoporus, H. carteri and C. pelagicus analyzed at $7.5 \mathrm{keV}$, the analysis spatial resolution is too low to be clearly observed crystals in Ca maps. The high spatial resolution maps of $D$. striatus and $W$. britannica (Fig. 3 ) show that Mn is not homogeneously distributed. In both placoliths, the Mn distribution forms a ring with elongated structures that are directly comparable to the calcite crystals of the rim radiating in the R-unit of the placoliths (following the R/V model of Young et al., 1992). The crystal shape and orientation are actually more easily observed in Mn maps than in Ca maps in both species. For species analyzed at ID21, the spatial resolution is high enough to clearly observe crystal organization for D. falcatus on both $\mathrm{Ca}$ and $\mathrm{Mn}$ maps (Fig. 4). In this species, $\mathrm{Ca}$ is more concentrated in the central disc than in the rays, whereas Mn shows a maximal concentration in an intermediate region between the central knob and the rays. D. striatus and W. britannica show a Mn ring-shape distribution at ID21similar to the one measured at ID22. C. leptoporus and $H$. carteri are depleted in $\mathrm{Mn}$ in comparison to the other species and its distribution is more homogeneous. Finally, contrary to $H$. carteri and C. leptoporus, the central area in $C$. pelagicus is easily identifiable on the Ca map, but is not individualized in the Mn map. C. pelagicus is also more enriched in Mn than other core-top samples, especially on the top side in Fig. 4. 

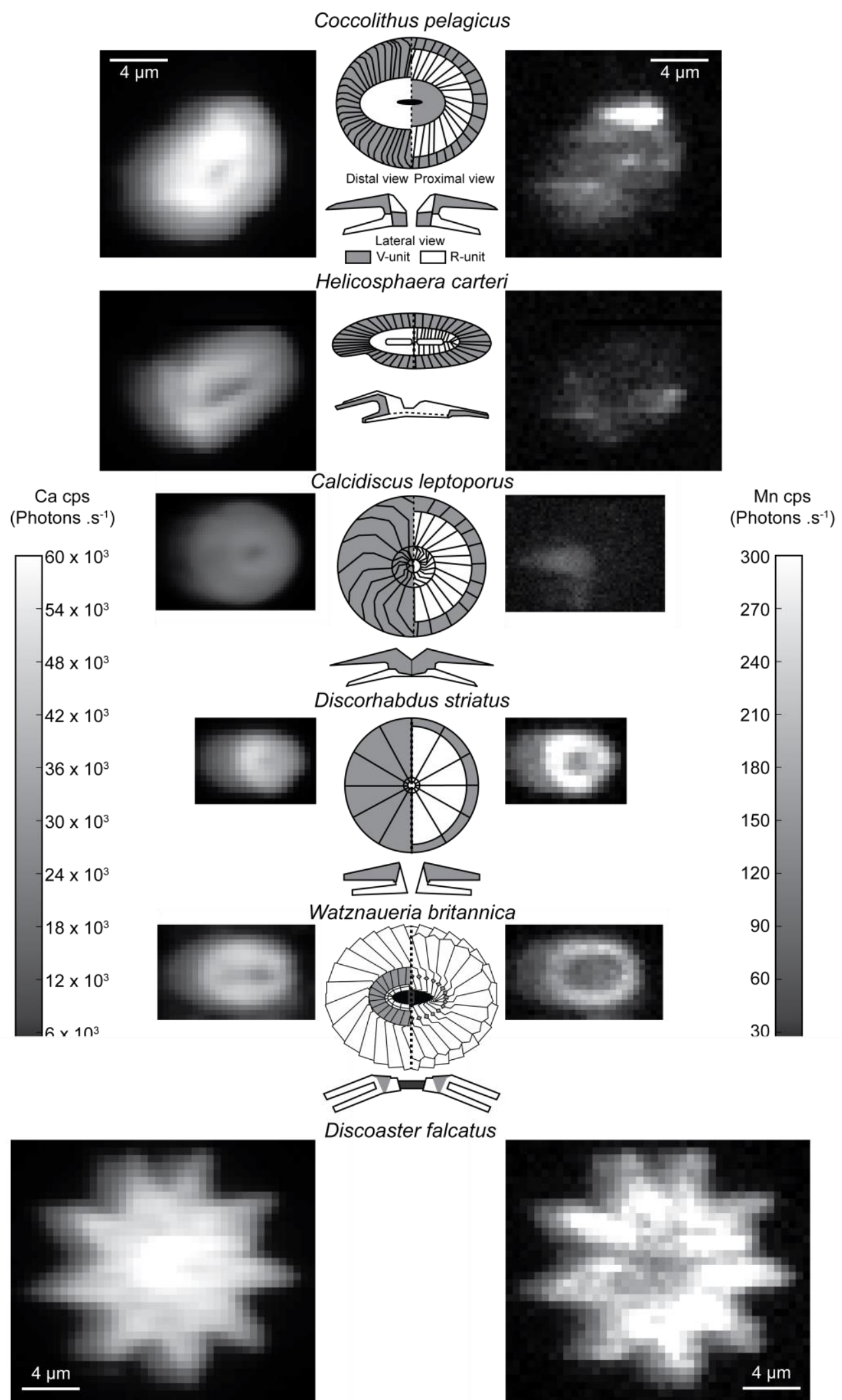

Discoaster falcatus

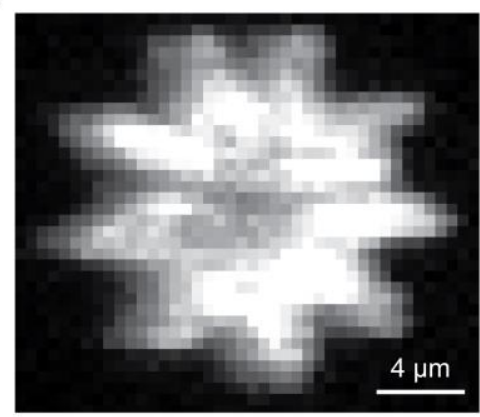

Fig. 4: Ca and Mn maps of D. striatus, W. britannica, D. falcatus, C. leptoporus, $H$. carteri and C. pelagicus $(7.5 \mathrm{keV})$. Both intensity gray scales are in photon counts per second. 3.3. Mn K-edge XANES 
The four analyzed nannofossils yielded similar Mn K-edge XANES spectra (Fig. 5). The peaks slightly differ in intensity, but their positions remain similar in the different zones of W. britannica (Supplementary Figure 1). All Mn XANES spectra are similar to the $\mathrm{MnCO}_{3}$ standard spectra (Fig. 5). The pre-peak at $6.55 \mathrm{keV}$ and the broad peak close to $6.56 \mathrm{keV}$ are recorded in all the nannofossils spectra. At higher energy, the peak above $6.57 \mathrm{keV}$ is often recorded at slightly lower energy in the nannofossils than in the standard. None of the nannofossils spectra display any characteristic peaks of either $\mathrm{KMnO}_{4}$ or $\mathrm{MnO}_{2}$ (Fig. 5). This indicates that $\mathrm{Mn}$ is distributed in the structure of the calcite platelets and only under the chemical form of calcite $(\mathrm{Ca}, \mathrm{Mn}) \mathrm{CO}_{3}$.

\begin{tabular}{|c|c|c|c|c|c|c|}
\hline & \multicolumn{2}{|c|}{ D. striatus/W. britannica } & D. falcatus & C. leptoporus & C. pelagicus & H. carteri \\
\hline $\begin{array}{c}\text { Background } \\
\text { contribution (\%) }\end{array}$ & $17 \mathrm{keV}$ & $7.5 \mathrm{keV}$ & $7.5 \mathrm{keV}$ & $7.5 \mathrm{keV}$ & $7.5 \mathrm{keV}$ & $7.5 \mathrm{keV}$ \\
\hline$>1$ & $\mathrm{~S}, \mathrm{Cl}, \mathrm{Cu}, \mathrm{Zn}, \mathrm{Br}$ & $\begin{array}{c}\mathrm{Na}, \mathrm{Mg}, \mathrm{Al}, \mathrm{S}, \\
\mathrm{Cl}, \mathrm{K}\end{array}$ & $\begin{array}{c}\mathrm{Al}, \mathrm{Si}, \mathrm{S}, \mathrm{K}, \\
\mathrm{Ti}, \mathrm{V}, \mathrm{Cr}\end{array}$ & $\begin{array}{c}\mathrm{Mg}, \mathrm{Al}, \mathrm{Si}, \mathrm{S}, \mathrm{Cl}, \mathrm{K}, \\
\mathrm{Ti}, \mathrm{V}, \mathrm{Mn}\end{array}$ & $\begin{array}{c}\mathrm{Al}, \mathrm{Si}, \mathrm{S}, \mathrm{K}, \\
\mathrm{Ti}, \mathrm{V}, \mathrm{Cr}\end{array}$ & $\begin{array}{c}\mathrm{Al}, \mathrm{Si}, \mathrm{S}, \mathrm{Cl}, \\
\mathrm{Mn}, \mathrm{Fe}\end{array}$ \\
\hline$<1$ & $\begin{array}{c}\mathrm{K}, \mathrm{Ca}, \mathrm{Ti}, \mathrm{V}, \mathrm{Cr}, \mathrm{Mn}, \\
\mathrm{Fe}, \mathrm{Rb}, \mathrm{Sr}\end{array}$ & $\begin{array}{c}\mathrm{Ca}, \mathrm{Ti}, \mathrm{Cr}, \\
\mathrm{Mn}, \mathrm{Fe}\end{array}$ & $\mathrm{Ca}, \mathrm{Mn}, \mathrm{Fe}$ & $\mathrm{Ca}, \mathrm{Fe}$ & $\mathrm{Ca}, \mathrm{Mn}, \mathrm{Fe}$ & $\mathrm{Ca}$ \\
\hline
\end{tabular}

Table 2: Background contributions (\%) to the element concentration (in cps) in the calcareous nannofossils analyzed at $7.5 \mathrm{keV}$ and $17 \mathrm{keV}$.

\section{Discussion}

The Ca maps reproduce the detailed shape of the analyzed nannofossils and thus allow a direct comparison of the crystalline organization and Mn distribution. The Mn distribution is clearly different between the pre-Quaternary and Quaternary nannofossils. Although fossil D. striatus, $W$. britannica and D. falcatus are from neither the same locality nor the same stratigraphic interval, they are enriched in Mn compared to modern C.pelagicus, C. leptoporus and H. carteri. $\mathrm{Mn}$ is not randomly distributed in the oldest nannofossils but rather forms discs with the inner parts far less concentrated in Mn than the outer parts (Figs. 3-4). The fact that the crystals are more easily observed in Mn maps than Ca maps is related to the direction of crystal growth. In Ca maps of placoliths, both shields (i.e. the discs formed by several calcite crystals; Young et al., 1997), are superposed, blurring the sutures between crystals. However, the direction of crystals in Mn maps is perfectly clear because it corresponds to only one crystal growth direction thus to one shield only (Suchéras-Marx et al., 2016b). In the case of D. falcatus, the center of the asterolith is less concentrated in Mn, which corresponds to the thick central knobs. Overall, Mn maps of all nannofossils from rock samples display a distribution in close relation with the crystalline organization of the nannofossils. In contrast, Quaternary nannofossils are depleted in Mn with no clear organization to its distribution. 
C. pelagicus is the only sample showing some Mn enrichment, and it is concentrated in one side of the placolith. Unfortunately, the spatial resolution limits the discussion regarding any potential relation with the crystalline organization.

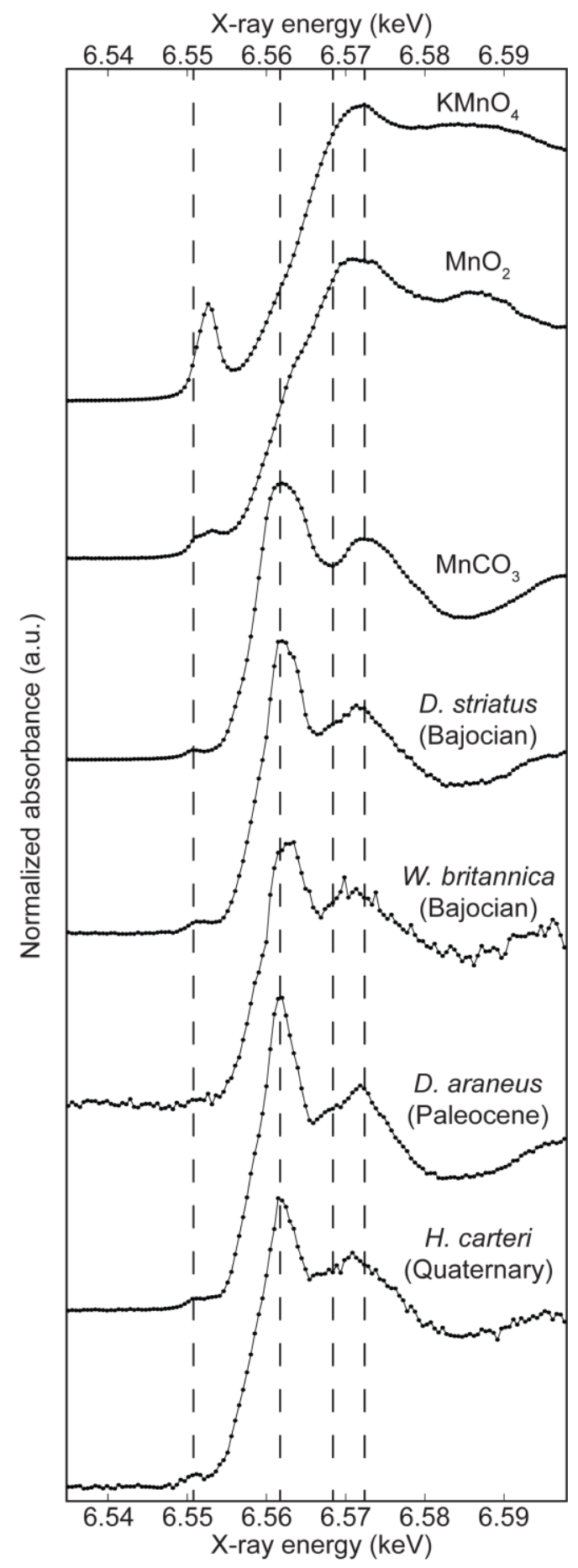

Fig. 5: Mn K-edge XANES spectra of D. striatus, W. britannica, D. falcatus and H. carteri compared to $\mathrm{KMnO}_{4}, \mathrm{MnO}_{2}$ and $\mathrm{MnCO}_{3}$ standards. Dashed vertical lines are guides for the eyes to follow $\mathrm{MnCO}_{3}$ characteristic spectroscopic features. 
The XANES analyses clearly show that, in all analyzed nannofossils, $\mathrm{Mn}$ is in the form of (Ca, $\mathrm{Mn}) \mathrm{CO}_{3}$. XANES spectra did not show contributions of oxidized Mn in our samples suggesting that Mn recorded in XRF maps did not come from surrounding organic matter or residual organic matter within the nannofossil crystals.

The very low Mn concentrations observed in well-preserved Quaternary C. leptoporus and $H$. carteri species show that their primary calcite is depleted in Mn in comparison with JurassicPaleocene nannofossils. Hence, the very low Mn concentrations in Quaternary nannofossils rule out the possibility that $\mathrm{Mn}$ is incorporated in nannofossils during intracellular secretion either for specific physiological function, as for example Mn-based UV shielding, or as a waste product considering its high concentration in coccolithophores (Ho et al., 2003). Moreover, the $\mathrm{Mn}$ concentration is unfortunately too low to be a useful environmental proxy. Secondly, $\mathrm{Mn}$ in nannofossils appears to be more likely related to diagenesis inducing the formation of calcite crusts slightly enriched in Mn. As the calcite crust grows in placoliths, it follows the crystal directions of one shield possibly in the interstice between the shields and/or on the distal shield (Suchéras-Marx et al., 2016a). In the case of D. falcatus, the central knobs - the thickest part of the nannofossil - is depleted in $\mathrm{Mn}$ in comparison to the central area region. Thus, the diagenetically-formed $\mathrm{CaCO}_{3}$ crusts smoothed the nannofossil shape forming less Mn-rich diagenetic calcite on the thick knobs and more on the surrounding thinner central disc. The secondary diagenetic calcitic crusts is generated by an interstitial fluid rich in $\mathrm{Ca}^{2+}$ and $\mathrm{HCO}_{3}{ }^{-}$ and in $\mathrm{Mn}^{2+}$ to a lesser extent, thus with high potential of calcite precipitation on calcareous nannofossils. Our conclusion is consistent with previous chemical observations of secondary calcite crusts being enriched in $\mathrm{Mg}$ (Prentice et al., 2014) and depleted in $\mathrm{Sr}$ lowering the $\mathrm{Sr} / \mathrm{Ca}$ (Dedert et al., 2014). The observation of Mn in calcareous nannofossils should then be used as an indicator of the presence of a diagenetic calcite crust, just as in foraminifera (Boyle et al., 1983).

In modern C. pelagicus, there is a slightly higher content of Mn and local enrichment, which is related to another type of diagenetic enrichment than that observed in D. striatus, W. britannica and D. falcatus. Because C. pelagicus was sampled in a core-top, the enrichment certainly occurred on the seafloor or possibly also in the water column and thus relates to very early diagenesis encrusting processes rather than to a late diagenesis like in rocks. This early encrusting may be related to the chemical characteristics of the Northern Atlantic with i) high saturation state $\left(\Omega_{\text {calcite }}>1\right.$, based on Lauvset et al., 2016$)$ in the water column and at the seafloor, which promotes calcite formation on calcite substrate like nannofossil and ii) high seawater $\left[\mathrm{Mn}^{2+}\right]$ in this region (van Hulten, et al., 2017). Such calcite encrusting is considered as a very 
early diagenesis process. However, secondary sedimentary diagenesis during rock formation is the main contributor of Mn-enriched calcite overgrowth as seen in Jurassic and Paleocene nannofossils. Potential early and late diagenesis may impact nannofossil elemental composition and thus a careful check, even for recent materials, is mandatory before any geochemical analyses can be conducted in order to measure proxies. This procedure could actually be done based on Mn concentration.

\section{Conclusion}

The potential use of calcareous nannofossil for paleoceanographical reconstructions based on their elemental geochemistry is in its early days thanks to the recent development of highresolution analytic tools which allow the analyses or even mapping of individual elements. Based on synchrotron nanoXRF and XANES, Mn distribution maps and valence were analyzed in Quaternary and Paleocene-Jurassic calcareous nannofossils selected from deep ocean coretops and land section rock samples, respectively. Despite our small sample size, we show here for the first time that core-top nannofossils are highly depleted in Mn by comparison with rock samples nannofossils. XANES analyses show that $\mathrm{Mn}$ is in the form of $(\mathrm{Ca}, \mathrm{Mn}) \mathrm{CO}_{3}$. Hence, its distribution is likely related to Mn-rich calcite crusts embedding calcareous nannofossils as in planktic foraminifera. A core-top nannofossil was slightly enriched in Mn which could be seen as indicative of incorporation of Mn during early diagenesis. Although the concentration of Mn in calcareous nannofossils may not yield significant paleoenvironmental or paleobiological evidence, it will definitely be a critical indicator of chemical preservation of calcareous nannofossils.

\section{Data Availability}

All data presented here are deposited in PANGAEA repositories in open access. D. striatus and W. britannica analyzed at $17 \mathrm{keV}$ (ESRF project EC811) are in 10.1594/PANGAEA.913811. All nannofossils analyzed at $7.5 \mathrm{keV}$ (ESRF project ES113) and presented in this study are in repository 10.1594/PANGAEA.913806. Mn-edge XANES data (ESRF project ES113) nannofossils and standards - presented in this study are in repository 10.1594/PANGAEA.913188. All nannofossils analyzed during ESRF project ES113 and not presented in this study are in repository 10.1594/PANGAEA.913810. 
Author contributions

BSM and FG designed the study with the contribution of ID and AS. BSM, FG, ID, AS, CR and RT conducted the analyses on both beamlines at ESRF. MPA, KHB and LB provided samples. BSM and AS performed the data treatment. BSM wrote the manuscript with contributions from all authors.

\section{Acknowledgments}

We acknowledge the ESRF for providing access to synchrotron radiation at the ID21 and ID22NI beamlines (proposals EC-811 and ES-113). The sample from Wilson Lake was provided by the International Ocean Discovery Program which we thank. BSM thanks two anonymous reviewers in a previous submission.

\section{References}

Astilleros, J.M., Pina, C.M., Fernández-Díaz, L., Putnis, A., 2002. Molecular-scale surface processes during the growth of calcite in the presence of manganese. Geochim. Cosmochim. Ac. 66, 3177-3189. doi: 10.1016/S0016-7037(02)00892-X

Aubry, M.-P., 2015. Cenozoic Coccolithophores: Discoasterales (CC-D). The Micropaleontology Press, New York, 388 pp.

Bendif, E.M., Probert, I., Carmichel, M., Romac, S., Hagino, K., de Vargas, C., 2014. Genetic delineation between and within the widespread coccolithophore morpho-species Emiliania huxleyi and Gephyrocapsa oceanica (Haptophyta). J. Phycol. 50, 140-148. doi: 10.1111/jpy.12147.

Bianconi, A., 1980. Surface X-ray absorption spectroscopy: Surface EXAFS and surface XANES. Applications of Surface Science 6, 392-418. doi: 10.1016/0378-5963(80)90024-0.

Bown, P.R., 1987. Taxonomy, evolution, and biostratigraphy of the late Triassic-early Jurassic calcareous nannofossils. The Palaeontological Association, London. 118 pp.

Boyle, E.A., 1983. Manganese carbonate overgrowths on foraminifera tests. Geochim. Cosmochim. Ac. 47, 1815-1819. doi: 10.1016/0016-7037(83)90029-7

Bruland, K.W., Lohan, C., 2003. Controls of trace metals in seawater, in: Elderfield, H. (Ed.), Treatise on Geochemistry. Elsevier, Amsterdam, pp. 23-47. doi: 10.1016/B0-08-0437516/06105-3

Cotte, M., Pouyet, E., Salomé, M., Rivard, C., De Nolf, W., Castillo-Michel, H., Fabris, T., Monico, L., Janssens, K., Wang, T., Sciau, P., Verger, L., Cormier, L., Dargaud, O., Brun, E., Bugnazet, D., Fayard, B., Hesse, B., Pradas del Real, A.E., Veronesi, G., Langlois, J., 
Balcar, N., Vandenberghe, Y., Solé, V.A., Kieffer, J., Barrett, R., Cohen, C., Cornu, C., Baker, R., Gagliardini, E., Papillon, E., Susini, J., 2017. The ID21 X-ray and infrared microscopy beamline at the ESRF: status and recent applications to artistic materials. J. Anal. Atom. Spectrom. 32, 477-493. doi: 10.1039/C6JA00356G

Dedert, M., Stoll, H.M., Kars, S., Young, J.R., Shimizu, N., Kroon, D., Lourens, L.J., Ziveri, P., 2014. Temporally variable diagenetic overgrowth on deep-sea nannofossil carbonates across Palaeogene hyperthermals and implications for isotopic analyses. Mar. Micropaleontol. 107, 18-31. doi: 10.1016/j.marmicro.2013.12.004

Dismukes, G.C., van Willigen, R.T., 2006. Manganese: The Oxygen-Evolving Complex \& Models Based in part on the article Manganese: Oxygen-Evolving Complex \& Models by Lars-Erik Andréasson \& Tore Vänngård which appeared in the Encyclopedia of Inorganic Chemistry, First Edition, in: King, R.B., Crabtree, R.H., Lukehart, C.M., Atwood, D.A., Scott, R.A. (Eds.), Encyclopedia of Inorganic Chemistry, Wiley. doi: 10.1002/0470862106.ia128

Gardin, S., Krystyn, L., Richoz, S., Bartolini, A., Galbrun, B., 2012. Where and when the earliest coccolithophores? Lethaia 45, 507-523. doi : 10.1111/j.1502-3931.2012.00311.x

Hermoso, M., Lefeuvre, B., Minoletti, F., de Rafélis, M., 2017. Extreme strontium concentrations reveal specific biomineralization pathways in certain coccolithophores with implications for the $\mathrm{Sr} / \mathrm{Ca}$ paleoproductivity proxy. Plos One 12, e0185655. doi: 10.1371/journal.pone.0185655

Herweg, J., 1913. Über das spektrum der Röntgenstrahlen. Deutschen Physikalischen Gesellschaft 15, 555-556.

Ho, T.-Y., Quigg, A., Finkel, Z.V., Milligan, A.J., Wyman, K., Falkowski, P.G., Morel, F.M.M., 2003. The elemental composition of some marine phytoplankton. J. Phycol. 39, 1145-1159. doi: 10.1111/j.0022-3646.2003.03-090.X

Lauvset, S.K., Key, R.M., Olsen, A., van Heuven, S., Velo, A., Lin, X., Schirnick, C., Kozyr, A., Tanhua, T., Hoppema, M., Jutterström, S., Steinfeldt, R., Jeansson, E., Ishii, M., Perez, F.F., Suzuki, T., Watelet, S., 2016. A new global interior ocean mapped climatology: the $1^{\circ} \times 1^{\circ}$ GLODAP version 2. Earth Syst. Sci. Data 8, 325-340. doi: 10.5194/essd-8-325-2016 Miller, K.G., Browning, J.V., Aubry, M.-P., Babila, T., Baluyot, R.D., Esmeray-Senlet, S., Feigenson, M.D., Karakaya, S., Lombardi, C.J., Makarova, M., McCreary, S., McLaughlin, P.P., Monteverde, D.H., Olsson, R.K., Smith, C.T., Sugarman, P.J., Wright, J.D., 2017. Wilson Lake site, in: Miller, K.G., Sugarman, P.J., Browning, J.V., et al. (Eds.), Proceedings 
of the Ocean Drilling Program, initial reports, volume 174AX (supplement). College Station, TX, 1-31. doi: 10.2973/odp.proc.174AXS.111.2017

Paquette, J., Reeder, R.J., 1995. Relationship between surface structure, growth mechanism, and trace element incorporation in calcite. Geochim. Cosmochim. Ac. 59, 735-749. doi: 10.1016/0016-7037(95)00004-J

Pavia, G., Enay, R., 1997. Definition of the Aalenian-Bajocian Stage boundary. Episodes 20, 16-22. doi: 10.18814/epiiugs/1997/v20i1/004

Pena, L.D., Cacho, I., Calvo, E., Pelejero, C., Eggins, S., Sadekov, A., 2008. Characterization of contaminant phases in foraminifera carbonates by electron microprobe mapping. Geochem. Geophy. Geosy. 9, Q07012. doi: 10.1029/2008GC002018

Prentice, K., Dunkley Jones, T., Lees, J., Young, J.R., Bown, P.R., Langer, G., Fearn, S., EIMF, 2014. Trace metal $(\mathrm{Mg} / \mathrm{Ca}$ and $\mathrm{Sr} / \mathrm{Ca})$ analyses of single coccoliths by Secondary Ion Mass Spectrometry. Geochim. Cosmochim. Ac.146, 90-106. doi: 10.1016/j.gca.2014.09.041

Reinhardt, P., 1972. Coccolithen. Kalkiges Plankton seit Jahrmillionen. Die Neue BrehmBücherei, A. Ziemsen Verlag, Lutherstadt Wittenberg 453.

Rickaby, R.E.M., Schrag, D.P., Zondervan, I., Riebesell, U., 2002. Growth rate dependence of Sr incorporation during calcification of Emiliania huxleyi. Global Biochem. Cy. 16, 1006. doi: 10.1029/2001GB001408

Siesser, W.G., 1977. Chemical composition of calcareous nannofossils. S. Afr. J. Sci. 73, 283285.

Stoll, H.M., Schrag, D.P., 2000. Coccolith Sr/Ca as a new indicator of coccolithophorid calcification and growth rate. Geochim. Cosmochim. Ac. 1, 1006 . doi: 10.1029/1999GC000015

Stoll, H.M., Shimizu, N., 2009. Micropicking of nannofossils in preparation for analysis by secondary ion mass spectrometry. Nat. Protoc. 4, 1038-1043. doi: 10.1038/nprot.2009.83

Stoll, H.M., Encinar, J.R., Alonso, J.I.G., Rosenthal, Y., Probert, I., Klaas, C., 2001. A first look at paleotemperature prospects from $\mathrm{Mg}$ in coccolith carbonate: Cleaning techniques and culture measurements. Geochem. Geophy. Geosy. 2, 2000GC000144. doi: 10.1029/2000GC000144

Stoll, H.M., Rosenthal, Y., Falkowski, P., 2002a. Climate proxies from Sr/Ca of coccolith calcite: calibrations from continuous culture of Emiliania huxleyi. Geochim. Cosmochim. Ac. 66, 927-936. doi: 10.1016/S0016-7037(01)00836-5 
Stoll, H.M., Ziveri, P., Geisen, M., Probert, I., Young, J.R., 2002b. Potential and limitations of $\mathrm{Sr} / \mathrm{Ca}$ ratios in coccolith carbonate: new perspectives from cultures and monospecific samples from sediments. Philos. Troy. Soc. A 360, 719-747. doi: 10.1098/rsta.2001.0966

Stoll, H.M., Shimizu, N., Arevalos, A., Matell, N., Banasiak, A., Zeren, S., 2007. Insights on coccolith chemistry from a new ion probe method for analysis of individually picked coccoliths. Geochem. Geophy. Geosy. 8, Q06020. doi: 10.1029/2006GC001546

Suchéras-Marx, B., Guihou, A., Giraud, F., Lécuyer, C., Allemand, P., Pittet, B., Mattioli, E., 2012. Impact of the Middle Jurassic diversification of Watznaueria (coccolith-bearing algae) on the carbon cycle and $\delta^{13} \mathrm{C}$ of bulk marine carbonates. Global Planet. Change 86-87, 92100. doi: 10.1016/j.gloplacha.2012.02.007

Suchéras-Marx, B., Giraud, F., Lena, A., Simionovici, A., 2016a. Picking nannofossils: How and why. J. Micropalaeontol. 36, 219-221. doi : 10.1144/10.1144jmpaleo2016-013

Suchéras-Marx, B., Giraud, F., Simionovici, A., Daniel, I., Tucoulou, R., 2016b. Perspectives on heterococcolith geochemical proxies based on high-resolution X-ray fluorescence mapping. Geobiology 14, 390-403. doi: 10.1111/gbi.12177

Suchéras-Marx, B., Mattioli, E., Allemand, P., Giraud, F., Pittet, B., Plancq, J., Escarguel, G., 2019. The colonization of the oceans by calcifying pelagic algae. Biogeosciences 16, 2501 2510. doi: 10.5194/bg-16-2501-2019

van Hulten, M., Middag, R., Dutay, J.C., de Baar, H., Roy-Barman, M., Gehlen, M., Tagliabue, A., Sterl, A., 2017. Manganese in the west Atlantic Ocean in the context of the first global ocean circulation model of manganese. Biogeosciences 14, 1123-1152. doi: 10.5194/bg-14$1123-2017$

Winter, A., Jordan, R.W., Roth, P.H., 1994. Biogeography of living coccolithophores in ocean waters, in: Winter, A., Siesser, W.G. (Eds.), Coccolithophores. Cambridge University Press, Cambridge, 161-178.

Young, J.R., Didymus, J.M., Bown, P.R., Mann, S., 1992. Crystal assembly and phylogenetic evolution in heterococcoliths. Nature 356, 516-518. doi: 10.1038/356516a0

Young, J.R., Bergen, J.A., Bown, P.R., Burnett, J.A., Fiorentino, A., Jordan, R.W., Kleijne, A., Van Niel, B.E., Romein, A.J.T., Von Salis, K., 1997. Guidelines for coccolith and calcareous nannofossil terminology. Palaeontology 40, 875-912 


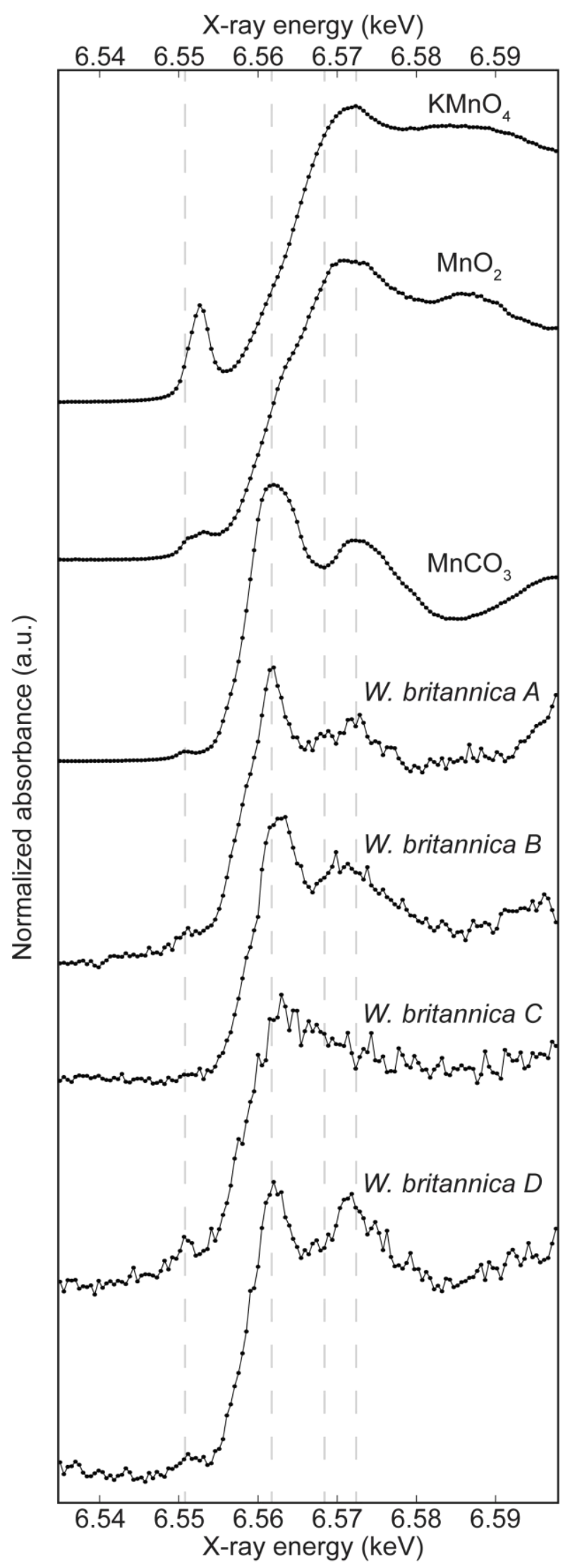

Supplementary Fig. 1: Mn K-edge XANES analyses of different parts of W. britannica, compared to $\mathrm{KMnO}_{4}, \mathrm{MnO}_{2}$ and $\mathrm{MnCO}_{3}$ standards. 